\title{
Młody mężczyzna z zaburzeniami przewodnictwa przedsionkowo-komorowego
}

\section{A young man with atrioventricular conduction disorders}

\author{
Paweł Kośmider ${ }^{1}$, Radosław Bartkowiak ${ }^{1}$, Beata Wożakowska-Kapłon ${ }^{1,2}$ \\ ${ }^{1}$ I Klinika Kardiologii i Elektroterapii Świętokrzyskiego Centrum Kardiologii w Kielcach \\ ${ }^{2}$ Wydział Lekarski i Nauk o Zdrowiu Uniwersytetu Jana Kochanowskiego w Kielcach
}

\section{Streszczenie}

Przedstawiono przypadek 34-letniego mężczyzny z blokiem lewej odnogi pęczka Hisa oraz blokiem przedsionkowo-komorowym II stopnia 2:1 bez organicznej choroby serca. Blok przedsionkowo-komorowy może być spowodowany przyczynami organicznymi oraz czynnościowymi. Od jego objawowości, poziomu zaawansowania oraz umiejscowienia w obrębie układu przewodzącego zależą wskazania do stałej stymulacji serca.

Słowa kluczowe: blok przedsionkowo-komorowy, stymulacja serca, blok lewej odnogi pęczka Hisa

Folia Cardiologica 2018; 13, 1: 96-98

\section{Wstęp}

Zaburzenia przewodzenia impulsów w obrębie układu bodźcoprzewodzącego serca mogą być przemijające lub stałe oraz wystąpić na każdym jego poziomie. Najczęściej przyczyną zaburzeń w obrębie układu przewodzącego serca jest jego uszkodzenie w wyniku niedokrwienia, zmian zapalnych lub procesów degeneracyjnych. Także leki antyarytmiczne oraz nadmierna aktywacja przywspółczulna oddziałują ujemnie na przewodzenie impulsów. Blok rzedsionkowo-komorowy (AV, atrioventricular) może być bezobjawowy lub powodować osłabienie, ograniczenie tolerancji wysiłku, mroczki przed oczami, zawroty głowy aż do utraty przytomności. Postępowanie lecznicze zależy od lokalizacji bloku i obecności objawów [1].

\section{Opis przypadku}

Trzydziestoczteroletni mężczyzna dotychczas nieleczony z powodu chorób przewlekłych został przyjęty do kliniki kardiologii z powodu trwającej od 3 miesięcy łatwej męc- zliwości podczas wysiłku fizycznego, osłabienia, znużenia. Przy przyjęciu do kliniki był w stanie dobrym, nie obserwowano odchyleń w badaniu przedmiotowym.

W zapisie elektrokardiograficznym (EKG) uwidoczniono rytm zatokowy o częstości 55/min, blok lewej odnogi pęczka Hisa. W badaniu echokardiograficznym zobrazowano prawidłową wielkość jam serca i frakcję wyrzutową lewej komory oraz asynchronię śródkomorową.

Nie stwierdzono obecności swoistych przeciwciał w klasie IgM i lgG przeciwko Borrelia burdgorferi.

W celu oceny wydolności fizycznej u chorego wykonano test wysiłkowy na bieżni ruchomej (według protokołu Bruce'a), który przerwano w drugiej minucie z powodu bloku AV II stopnia 2:1 i zawrotów głowy. W 48-godzinnym monitorowaniu EKG metodą Holtera obserwowano bradykardię zatokową, liczne epizody bloku AV II stopnia 2:1 oraz dwie pauzy $(9,8$ s i 5,7 s w mechanizmie bloku AV III stopnia) (ryc. 1, 2) [2]. W trakcie monitorowania chory zgłaszał liczne epizody zawrotów głowy, które odpowiadały czasowo zmianom zapisu EKG w trakcie monitorowania. Z uwagi na zgłaszane objawy oraz udokumentowane 


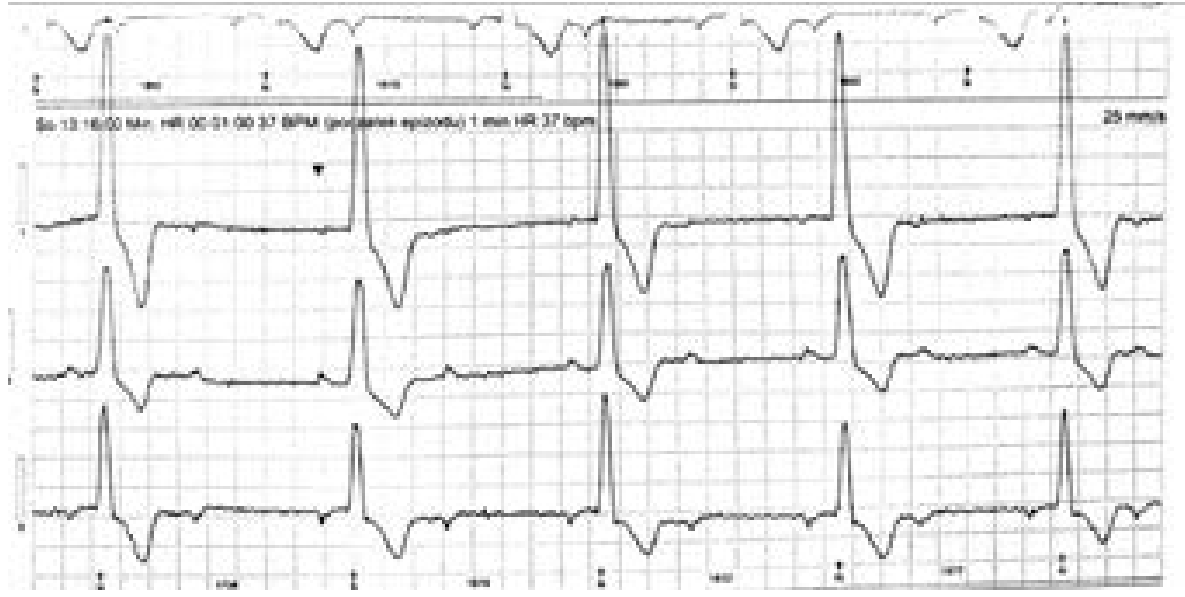

Rycina 1. Rytm zatokowy, blok przedsionkowo-komorowy II stopnia 2:1, blok lewej odnogi pęczka Hisa

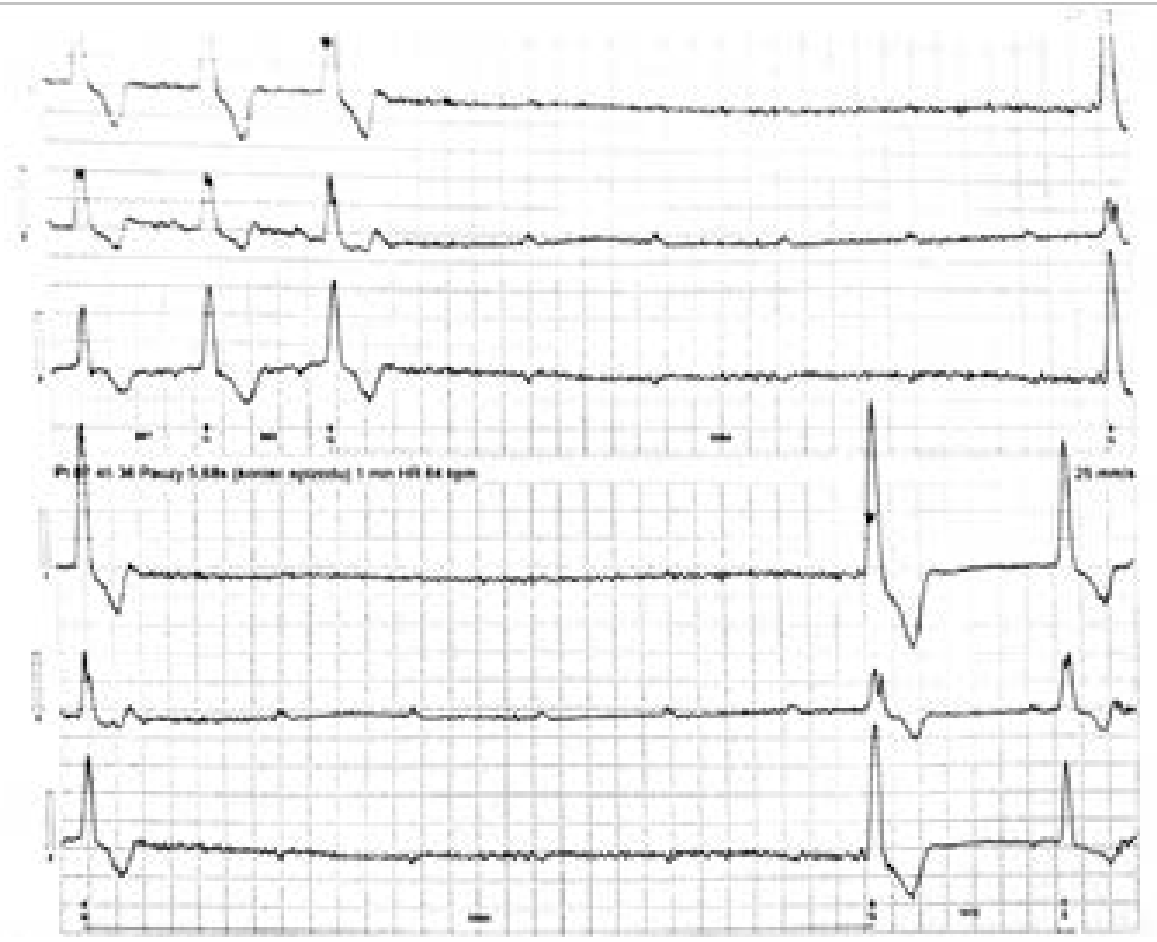

Rycina 2. Rytm zatokowy, blok przedsionkowo-komorowy III stopnia, pauza 5,68 s

zaburzenia przewodnictwa przedsionkowo-komorowego pod postacią bloku AV II stopnia 2:1 i bloku AV III stopnia pacjenta zakwalifikowano do implantacji kardiostymulatora dwujamowego [3].

\section{Omówienie}

U przedstawianego pacjenta przy przyjęciu opisywano blok lewej odnogi pęczka Hisa (LBBB, left bundle branch block) o nieznanym czasie trwania. W trakcie testu wysiłkowego na bieżni ruchomej oraz badania EKG metodą Holtera obser- wowano blok II stopnia 2:1 oraz 2-krotnie pauzy w mechanizmie bloku AV III stopnia. W przypadku bloku III stopnia żadne z pobudzeń zainicjowanych w komórkach węzła zatokowego nie zostaje przewiedzione do komór. Do zaburzeń przewodnictwa w obrębie układu bodźcoprzewodzacego może dojść na podłożu chorób organicznych lub zaburzeń czynnościowych. Do najczęstszych przyczyn organicznych można zaliczyć chorobę niedokrwienną serca, zawał serca, choroby reumatologiczne, a także zmiany zwyrodnieniowe w przebiegu choroby Lenegre'a-Leva [1]. Do powstania bloku AV może dojść także z przyczyn jatrogennych takich 
jak ablacja łącza przedsionkowo-komorowego lub operacje kardiochirurgiczne [4]. Czynnościowe przyczyny zaburzeń przewodnictwa AV mogą być konsekwencją stosowanych leków antyarytmicznych i psychotropowych, zaburzeń elektrolitowych, niedoczynności tarczycy i hiperwagotonii $[5,6]$. $\mathrm{U}$ pacjentów bez organicznej choroby serca z blokiem AV, w szczególności III stopnia, należy wykluczyć możliwość występowania boreliozy [7]. Blok AV może być pierwszą manifestacją kliniczną boreliozy i przebiegać ze zmiennym stopniem zaawansowania [8, 9]. W toku przeprowadzonych badań u opisywanego chorego wykluczono etiologię niedokrwienną, zapalną oraz organiczną występowania bloku przedsionkowo-komorowego.

Wywiad dotyczący czasu trwania objawów przemawiał u chorego za procesem przewlekłym, postępującym.
Wydaje się więc, że zarówno LBBB oraz blok AV 2:1 i epizody bloku AV III stopnia najprawdopodobniej były spowodowane zmianami degeneracyjnymi w obrębie układu bodźcoprzewodzącego serca.

W związku z tym zgodnie z zaleceniami Europejskiego Towarzystwa Kardiologicznego (ESC, Euroepan Society of Cardiology) (klasa zaleceń Ic) wskazane było implantowanie układu stymulującego serce na stałe [3]. W trwającej miesiąc obserwacji chory nie zgłaszał występujących początkowo objawów oraz podawał znaczne zwiększenie tolerancji wysiłku.

\section{Konflikt interesów}

Autorzy deklarują brak konfliktu interesów.

\section{Abstract}

We present a case of a 34-year-old man with left bundle branch block and $2^{\text {nd }}$ degree atrioventricular block 2:1 without organic heart disease. The atrioventricular block may be caused by organic and functional causes. Its symptoms, level of advancement and placement within the conductive system depend on indications for constant heart stimulation.

Key words: atrioventricular block, cardiac pacing, left bundle branch block

Folia Cardiologica 2018; 13, 1: 96-98

\section{Piśmiennictwo}

1. Zipes D, Libby P, Bonow R, Braunwald E. Braunwald's heart disease. 7th ed. Elselvier, Philadelphia 2007: 831-836.

2. Baranowski R, Wojciechowski D, Maciejewska M. Zalecenia dotyczące stosowania rozpoznań elektrokardiograficznych. Dokument opracowany przez Grupę Roboczą powołaną przez Zarząd Sekcji Elektrokardiologii Nieinwazyjnej i Telemedycyny Polskiego Towarzystwa Kardiologicznego. Kardiol Pol. 2010; 68(supl. IV).

3. Polska K. Wytyczne ESC dotyczące stymulacji serca i terapii resynchronizującej w 2013 roku. Kardiol Pol. 2013; 71(V): 133-192, doi: 10.5603/kp.2013.0182.

4. Roten L, Wenaweser P, Delacrétaz E, et al. Incidence and predictors of atrioventricular conduction impairment after transcatheter aortic valve implantation. Am J Cardiol. 2010; 106(10): 1473-1480, doi: 10.1016/j.amjcard.2010.07.012, indexed in Pubmed: 21059439.

5. Strasberg B, Lam W, Swiryn S, et al. Symptomatic spontaneous paroxysmal AV nodal block due to localized hyperresponsiveness of the
AV node to vagotonic reflexes. Am Heart J. 1982; 103(5): 795-801, indexed in Pubmed: 7072584.

6. Eraker SA, Wickamasekaran R, Goldman S. Complete heart block with hyperthyroidism. JAMA. 1978; 239(16): 1644-1646, indexed in Pubmed: 580298.

7. Bhattacharya IS, Dweck M, Francis M. Lyme carditis: a reversible cause of complete atrioventricular block. J R Coll Physicians Edinb. 2010; 40(2): 121-122, doi: 10.4997/JRCPE.2010.207, indexed in Pubmed: 21125053.

8. Semmler D, Blank R, Rupprecht H-J. Complete AV block in Lyme carditis: an important differential diagnosis. Clin Res Cardiol. 2010; 99(8): 519-526, doi: 10.1007/s00392-010-0152-8, indexed in Pubmed: 20464556.

9. Swinnen Jo, Moerenhout C, Cools FJC. Cardiac conduction disturbances in Lyme disease. Acta Cardiol. 2003; 58(3): 211-214, doi: 10.2143/AC.58.3.2005282, indexed in Pubmed: 12846512. 